\title{
Keragaan Varietas Tebu Unggul Baru pada Fase Pembibitan dengan Pemberian Nano Silika
}

\author{
The Performance of New Superior Cane Varieties in Seedling Phase by Application of Nano \\ Silica \\ Vega Kartika Sari*1, dan Kacung Haryono \\ ${ }^{1,2}$ Fakultas Pertanian, Universitas Jember, J1. Kalimantan No. 37, Kabupaten Jember, Jawa Timur. \\ e-mail: *vegakartikas@unej.ac.id
}

\begin{abstract}
ABSTRAK
Tebu merupakan akumulator silika yang berarti memerlukan banyak asupan silika. Pupuk silika (Si) dapat berasal dari berbagai sumber dan terobosan teknologi saat ini tersedianya Si dalam bentuk nano. Beberapa varietas tebu unggul baru belum diuji pada lahan marginal. Tujuan penelitian ini untuk mengetahui pengaruh pemberian nano silika terhadap pertumbuhan fase bibit beberapa varietas unggul baru pada tanah entisol. Rancangan penelitian ini menggunakan Rancangan Acak Kelompok Faktorial dengan 2 faktor. Faktor pertama aplikasi nano Si (S) terdiri atas aplikasi nano Si 0\% (S1) dan aplikasi nano Si 30\% (S2). Faktor kedua varietas unggul baru terdiri atas Bululawang (V1), NX-01 (V2), NX-02 (V3), dan VMC 86-550 (V4). Hasil penelitian menunjukkan pemberian nano Si tidak berpengaruh nyata pada pertumbuhan tebu fase pembibitan, sedangkan varietas dan interaksi nano Si x V berpengaruh nyata terhadap pertumbuhan tebu. Varietas VMC 86-550 menunjukkan rata-rata pertumbuhan yang lebih baik pada seluruh variabel pengamatan.

Kata kunci: nano silika; tebu; varietas unggul baru

ABSTRACT

Sugarcane is a silica accumulator, which means it requires a lot of silica intake. Silica (Si) fertilizers can come from various sources and current technological breakthroughs are the availability of Si in nano form. Several new varieties of sugarcane have not been tested on marginal land. The purpose of this study was to determine the effect of nano silica on the growth of several new high yielding varieties on entisol soil. The research design used factorial randomized block design with 2 factors. The first factor of nano Si (S) application consists of nano Si application 0\% (S1) and nano Si application $30 \%$ (S2). The factors for the two new varieties consist of Bululawang (V1), NX-01 (V2), NX-02 (V3), and $V M C$ 86-550 (V4). The results showed that the administration of nano Si had no significant effect on the growth of sugarcane in the nursery phase, while the variety and interaction of nano Si $x$ V had a significant effect on the growth of sugarcane. Variety VMC 86-550 showed a better average growth in all observation variables.
\end{abstract}

Keywords: nano silica; sugarcane; new superior varieties 


\section{PENDAHULUAN}

Tebu (Saccharum officinarum L.) merupakan tanaman penting yang bernilai ekonomi tinggi dan dipakai sebagai bahan baku utama penghasil gula. Tanaman ini sangat dibutuhkan seiring meningkatnya pertambahan penduduk di negeri ini dan meningkatnya konsumsi gula, namun produksi yang dihasilkan belum dapat mengimbanginya.

Produktivitas tebu dipengaruhi oleh lingkungan biotik dan abiotik. Lingkungan abiotik salah satunya ialah penurunan tingkat kesuburan lahan pertanaman tebu (Basuki dan Sari, 2019). Pengambilan unsur hara secara terus menerus oleh tanaman tanpa diimbangi dengan aplikasi pemupukan, akan mengakibatkan defisiensi unsur hara. Salah satu contoh kasus penyerapan unsur hara yang terus diambil tanaman tebu dalam jumlah besar namun dalam kegiatan budidayanya tidak diimbangi dengan aplikasi pemupukan adalah unsur hara silika (Si).

$\mathrm{Si}$ sebagai unsur bermanfaat pada tanaman tebu memiliki banyak peran positif dalam pertumbuhan dan produksi tanaman tebu (Pikukuh et al., 2015). Si juga berperan dalam ketahanan tanaman terhadap cekaman biotik. Menurut Fitriani dan Haryani (2016), Si berperan dalam memperkuat jaringan tanaman, memperkuat batang tanaman dan akar yang dapat melancarkan transportasi air, dan meningkatkan ketahanan tanaman terhadap hama dan penyakit tanaman. Si merupakan unsur hara bermanfaat bagi tanaman tebu dan diserap dalam jumlah yang lebih besar dari unsur hara lainnya, bahkan melebihi serapannya terhadap air. Tanaman ini menyerap unsur hara $\mathrm{Si}$ sebesar 500-700 kg/ha, sementara pada penyerapan unsur hara makronya menyerap 50-500 kg $\mathrm{N} / \mathrm{ha}, 100-300 \mathrm{~kg} \mathrm{~K} / \mathrm{ha}$, dan 40-80 kg P/ha (Syahri et al., 2016). Beberapa sumber Si yang dapat digunakan sebagai pupuk antara lain abu bagas, Si Plus-HS, dan Formula Si (Hartatik et al., 2015). Pikukuh et al. (2015) dan Syahri et al. (2016) menggunakan pupuk Si yang diproses dengan menggunakan teknologi nano dalam penelitiannya pada tanaman tebu. Menurut Pikukuh et al. (2015), dengan menggunakan produk pupuk berteknologi nano, hasil pertanian yang optimal diharapkan dapat dicapai dengan mengaplikasikan jumlah pupuk yang lebih sedikit dibandingkan dengan menggunakan pupuk konvensional, sehingga penggunaan pupuk akan sangat efisien, efektif, dan dapat menurunkan biaya produksi.

Varietas Bululawang (BL) merupakan varietas yang dirilis P3GI Tahun 2004 dan telah secara luas digunakan oleh petani tebu, dan varietas ini cocok dikembangkan untuk tanah bertekstur pasir geluhan. Varietas VMC 86-550 dirilis oleh PTPN XI Tahun 2012, dan diketahui cocok dikembangkan untuk lahan sawah atau tegalan. Pada Tahun 2019, PTPN X merilis beberapa klon tebu unggul baru diantaranya NX-01 dan NX-02. Varietas unggul baru tersebut umumnya direkomendasikan pada lahan optimal dan belum diuji pada lahan marginal seperti pada tanah entisol. Tujuan penelitian ini ialah 
untuk mengetahui keragaan beberapa varietas tebu unggul baru pada lahan entisol dan respon pertumbuhan tebu terhadap pemberian Si.

\section{METODE PENELITIAN}

Penelitian dilaksanakan pada bulan Juli 2020 sampai September 2020 di Greenhouse yang berlokasi di Kecamatan Tegalampel, Kabupaten Bondowoso. Bahan tanam yang digunakan ialah varietas tebu unggul baru sebanyak 5 varietas yaitu NX 01, NX 02, NX 03, VMC 86-550, dan BL (kontrol) yang berupa bagal mata satu. Bahan lainnya yang dibutuhkan yaitu polibag ukuran $10 \mathrm{~kg}$, NPK, tanah entisol, dan pupuk powder nano Silika.

Penelitian ini menggunakan metode Rancangan Acak Kelompok Faktorial yang terdiri dari 2 faktor yaitu aplikasi pupuk nano Silika (faktor pertama), dan varietas tebu (faktor kedua). Faktor pertama terdiri atas 2 taraf yaitu: S1 = Konsentrasi 0\%; S2 = Konsentrasi 30\%. Aplikasi nano Si diberikan sebanyak 2 kali dan dengan cara dikocor ke tanah. Faktor kedua terdiri atas 4 taraf yaitu: V1= BL (Kontrol); V2= NX 01; V3= NX 02; V4=VMC 86-550.

Variabel pengamatan meliputi tinggi tanaman, jumlah daun, jumlah anakan, lebar daun, diameter batang. Pengamatan dilakukan pada 35 HST. Data yang diperoleh dianalisis dengan Analysis of Variance (ANOVA) pada tingkat kepercayaan 95\%, dan apabila berbeda nyata dilanjutkan dengan Uji Tukey taraf $5 \%$.

Sebagai data penunjang, pengamatan juga dilakukan pada intensitas serangan hama penyakit yang muncul. Untuk kasus penggerek pucuk, setiap batang tebu dinyatakan terserang apabila terdapat tanda serangan S. nivella intacta, baik yang larvanya berhasil menembus titik tumbuh maupun tidak. Intensitas kerusakan dihitung dengan menggunakan persentase antara tanaman yang terserang dengan tanaman yang diamati, sesuai dengan penelitian yang dilakukan Sudarsono et al. (2011). Kriteria intensitas serangan disajikan pada Tabel 1.

Tabel 1. Standar Serangan Hama Penggerek Pucuk Pada tanaman Tebu

\begin{tabular}{lllc}
\hline Tingkat Serangan & Penggerek & Tingkat Seangan & Penggerek \\
Umur $<6$ Bulan & Pucuk & Umur $>6$ Bulan & Pucuk \\
\hline Ringan & $<3 \%$ & Ringan & $<7 \%$ \\
Sedang & $3-5 \%$ & Sedang & $7-10 \%$ \\
Berat & $>5 \%$ & Berat & $>10 \%$ \\
\hline
\end{tabular}

Sumber: Juklak PHT Cinta Manis (2010) dalam Meidalima dan Kawaty (2015) 


\section{HASIL DAN PEMBAHASAN}

Hasil analisis data menggunakan sidik ragam dari variabel pengamatan disajikan pada Tabel 2 berikut ini. Berdasarkan hasil analisis ragam (Tabel 2), menunjukkan aplikasi silika tidak berpengaruh nyata hampir pada semua variabel pengamatan, kecuali lebar daun, demikian pula untuk interaksi silika dan varietas. Sebaliknya, perlakuan varietas menunjukkan pengaruh berbeda nyata pada hampir semua variabel pengamatan kecuali diameter batang. Hal tersebut sejalan dengan yang diungkapkan Siswanto et al. (2019), adanya beda nyata antar jenis klon, dan sebaliknya pada jenis arang (sumber Si), menunjukkan pengaruh genetik dari klon lebih berpengaruh terhadap pertumbuhan tanaman dari pada jenis arang yang diaplikasikan. Hasil analisis uji lanjut disajikan pada Tabel 3 berikut ini.

Tabel 2. Rangkuman F-hitung dari hasil analisis ragam pada seluruh variabel pengamatan

\begin{tabular}{lccc}
\hline Variabel Pengamatan & \multicolumn{3}{c}{ F Hitung } \\
\cline { 2 - 4 } & Aplikasi Silika $(\mathrm{S})$ & Varietas $(\mathrm{V})$ & Interasi $(\mathrm{S} \mathrm{xV})$ \\
\hline Tinggi tanaman & $0,01 \mathrm{~ns}$ & $4,63 *$ & $0,44 \mathrm{~ns}$ \\
Diameter batang & $0,18 \mathrm{~ns}$ & $1,09 \mathrm{~ns}$ & $0,55 \mathrm{~ns}$ \\
Jumlah daun & $0,69 \mathrm{~ns}$ & $5,82 *$ & $0,28 \mathrm{~ns}$ \\
Lebar daun & $16,14 *$ & $8,89 *$ & $4,57 *$ \\
Jumlah anakan & $0,36 \mathrm{~ns}$ & $3,33 *$ & $0,55 \mathrm{~ns}$ \\
\hline
\end{tabular}

Keterangan: * = berbeda nyata; $\mathrm{ns}=$ berbeda tidak nyata.

Tabel 3. Rekapitulasi hasil analisis uji lanjut data pengamatan

\begin{tabular}{|c|c|c|c|c|c|}
\hline Perlakuan & $\begin{array}{l}\text { Tinggi } \\
\text { Tanaman }\end{array}$ & $\begin{array}{c}\text { Diameter } \\
\text { Batang }\end{array}$ & Jumlah Daun & Lebar Daun & $\begin{array}{l}\text { Jumlah } \\
\text { Anakan }\end{array}$ \\
\hline \multicolumn{6}{|c|}{ (S) Aplikasi Nano Silika } \\
\hline S1 & 110,9 & 0,88 & 7,2 & $2,4 a$ & 0,8 \\
\hline $\mathrm{S} 2$ & 110,8 & 0,85 & 7,4 & $1,4 \mathrm{~b}$ & 0,6 \\
\hline \multicolumn{6}{|c|}{ (V) Varietas } \\
\hline V1 & $104,2 \mathrm{ab}$ & 0,92 & $7,2 \mathrm{ab}$ & $2,3 a$ & $0,7 \mathrm{ab}$ \\
\hline V2 & $99,0 \mathrm{~b}$ & 0,72 & $6,3 b$ & $1,0 \mathrm{a}$ & $0,2 b$ \\
\hline V3 & $101,3 b$ & 0,90 & $7,7 \mathrm{a}$ & $1,7 \mathrm{ab}$ & $0,7 \mathrm{ab}$ \\
\hline V4 & $138,8 \mathrm{a}$ & 0,93 & $8,0 \mathrm{a}$ & $2,6 \mathrm{a}$ & $1,2 \mathrm{a}$ \\
\hline \multicolumn{6}{|c|}{ Interaksi } \\
\hline $\mathrm{S} \times \mathrm{V}$ & ns & ns & ns & $*$ & ns \\
\hline
\end{tabular}

Keterangan: * = berbeda nyata; ns = berbeda tidak nyata. Angka yang didampingi huruf sama pada kolom yang sama, tidak berbeda nyata pada uji Tukey 5\%

Tebu merupakan salah satu tanaman akumulator Si. Tidak ada perbedaan yang nyata untuk perlakuan silika dimungkinkan karena pengamatan pada fase pembibitan yang berumur 35 HST belum menunjukkan pengaruh dari Si, dengan kata lain Si yang diberikan sebanyak 2 kali belum diakumulasikan secara optimal, sehingga tidak berbeda dengan tanpa Si. Penelitian Pikukuh et al. (2016) tentang pengaruh frekuensi dan konsentrasi silika terhadap parameter jumlah daun, tinggi tanaman tebu umur 5 bulan setelah tanam (BST) menunjukkan tidak berbeda nyata pada konsentrasi $30 \%$ pada frekuensi $1-4$ 
kali aplikasi $\mathrm{Si}$, dan menunjukkan perbedaan nyata pada pengamatan umur 7 BST. Hal tersebut menunjukkan bahwa tanaman tebu yang terlalu muda (fase pembibitan) belum menunjukkan pengaruh dari akumulasi silika terhadap pertumbuhannya. Hasil penelitian yang dilakukan oleh Mulyadi et al. (2007) dalam Pikukuh et al. (2016) juga menunjukkan aplikasi pemupukan Si pada tanah pada dosis tertentu dapat meningkatkan tinggi tanaman tebu secara nyata pada umur 4,5 bulan. Lebih lanjut Mulyadi et al. (2007) dalam Pikukuh et al. (2016) menyebutkan efektifitas pemupukan Si meningkatkan pertumbuhan tinggi tanaman secara signifikan ketika tanaman berumur 3 bulan. Berdasarkan hal tersebut, menunjukkan bahwa efektifitas pemupukan Si pada tebu dapat diketahui pada umur diatas 2 bulan.

Berdasarkan hasil analisis faktor utama yaitu varietas, menunjukkan bahwa varietas VMC 86-550 menunjukkan pertumbuhan yang lebih tinggi pada semua parameter pertumbuhan. Untuk jumlah anakan, menurut Insan (2010) dalam Siswanto et al., (2019), jenis klon yang memiliki jumlah anakan yang tinggi berarti kemampuan tumbuh mata tunasnya lebih cepat dan perkembangan akarnya lebih baik. Diameter batang merupakan parameter yang dapat digunakan untuk mengetahui produksi tanaman tebu. Dalam hal ini, tidak ada beda nyata antar varietas, namun rata-rata diameter batang terbesar adalah pada varietas VMC 86-550.

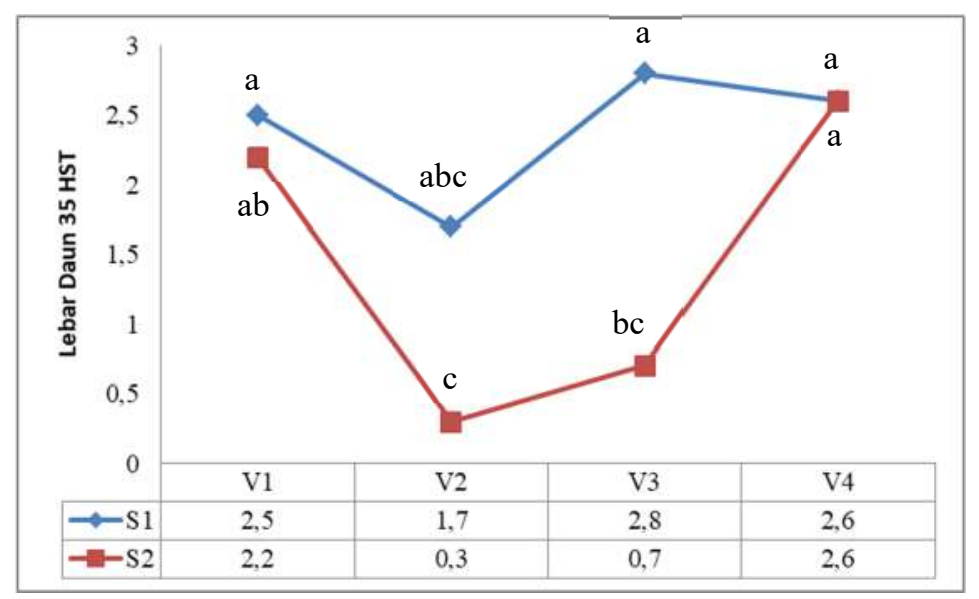

Gambar 1. Interaksi pemupukan nano silika dan varietas terhadap lebar daun

Berdasarkan hasil analisis sidik ragam bahwa interaksi silika dan varietas berpengaruh nyata terhadap lebar daun (Tabel 2). Menurut Syekfani (2000) dalam Siswanto et al. (2019), unsur hara yang tersedia dan dapat diserap tanaman dengan baik berpengaruh pada pertumbuhan daun yang lebih lebar dan fotosintesis yang terjadi lebih banyak. Berdasarkan Gambar 1, interaksi varietas (V) dengan tanpa silika (S1) yang tertinggi ialah Varietas NX-02 (V3) memberikan lebar daun terbesar yaitu 2,8 cm, dan tidak berbeda nyata dengan tiga varietas unggul lainnya. Interaksi varietas (V) dengan perlakuan silika $30 \%$ (S2) yang tertinggi ialah varietas VMC (V4) yang memberikan lebar daun sebesar 2,6 cm, dan berbeda dengan varietas lainnya. Menurut Trisnawati et al. (2017), perbedaan kemampuan tanaman untuk 
menyerap unsur silika tersedia dalam tanah menyebabkan perbedaan silika yang terakumulasi di dalam tanaman.

Varietas V4 disisi lain menunjukkan lebar daun yang tidak berbeda nyata, antara dipupuk silika atau pun tidak (Gambar 1). Hal tersebut menunjukkan pengaruh genetik pada varietas V4 lebih berpengaruh pada pertumbuhan lebar daun daripada faktor lingkungan, yang dalam hal ini aplikasi silika. Hasil pengamatan pendukung mengenai tingkat serangan hama menunjukkan bahwa serangan yang muncul yaitu penggerek pucuk. Gejala serangan terlihat pada helai daun pucuk yang berlubang. Serangan penggerek pucuk sebesar $4,17 \%$ pada tanaman yang berumur $<6$ bulan termasuk kategori sedang menurut Juklak PHT Cinta Manis (2010) dalam Meidalima dan Kawaty (2015). Serangan tersebut pada tanaman yang tidak diaplikasikan pupuk nano Si yaitu pada varietas NX-02 (V3), sedangkan pada tanaman yang diaplikasikan pupuk nano Si belum menunjukkan gejala serangan. Berdasarkan deskripsi varietas, varietas BL termasuk peka terhadap penggerek pucuk, NX-01 dan NX-02 termasuk varietas yang tahan, dan varietas VMC 86-550 termasuk toleran. Adanya serangan pada varietas tahan (NX-02) tersebut dapat disebabkan karena pertama, tidak diaplikasikan silika. Silika berfungsi untuk meminimalkan cekaman biotik pada tanaman. Hasil penelitian Pikukuh et al (2016), aplikasi 4 kali pemupukan Si nano memberikan tingkat kerusakan batang paling kecil akibat serangan penggerek batang sebesar 11,12\%, sementara batang tebu yang tidak diaplikasikan pupuk Si nano terjadi kerusakan sebesar 23,82\%. Hal tersebut disebabkan adanya kristal Si dalam jaringan epidermis penutup daun atau batang sehingga menghindari serangan penggerek. Rahang serangga akan rusak bila menggigit kristal Si. Kedua, umur tanaman tebu. Menurut Meidalima dan Kawaty (2015), kondisi tanaman tebu memasuki fase pertunasan merupakan kondisi yang sangat mendukung bagi perkembangan hama penggerek pucuk. Ketiga, kondisi iklim. Penggerek pucuk merupakan hama dominan dijumpai pada tanaman tebu dataran rendah yang basah dan memiliki tingkat kelembaban udara relatif tinggi (Meidalima dan Kawaty, 2015).

\section{KESIMPULAN}

Berdasarkan hasil penelitian dapat disimpulkan bahwa aplikasi silika tidak berpengaruh nyata pada semua variabel pertumbuhan tebu pada fase pembibitan. Hal tersebut dapat disebabkan karena silika belum diakumulasi optimal sehingga pengaruhnya belum tampak. Varietas VMC 86-550 menunjukkan keragaan tanaman yang lebih baik dari pada varietas lainnya, dan pada fase pembibitan faktor genetik pada varietas tersebut lebih berpengaruh pada pertumbuhan daripada faktor lingkungan. Serangan hama penggerek pucuk tergolong sedang, dialami tanaman yang tidak diaplikasikan silika dan juga dapat dipicu oleh umur tanaman dan kondisi iklim setempat. 


\section{UCAPAN TERIMA KASIH}

Penulis mengucapkan terima kasih kepada Lembaga Pusat Penelitian dan Pengabdian kepada Masyarakat Universitas Jember yang telah memberikan kesempatan untuk mengembangkan ilmu pengetahuan melalui kegiatan Penelitian Dosen Pemula Sumber Dana DIPA Tahun 2020 sesuai surat penugasan dengan nomor : 2677/UN25.3.1/LT/2020.

\section{DAFTAR PUSTAKA}

Basuki dan Sari, V.K. 2019. Efektifitas Dolomit dalam Mempertahankan pH Tanah Inceptisol Perkebunan Tebu Blimbing Djatiroto. Buletin Tanaman Tembakau, Serat \& Minyak Industri 11(2): 58-64

Fitriani, H.P., dan Haryanti, S. 2016. Pengaruh Penggunaan Pupuk Nanosilika Terhadap Pertumbuhan Tanaman Tomat (Solanum lycopersicum) var. Bulat. Anatomi dan Fisiologi 24 (1): 24-31

Hartatik, D., Wijaya, K.A., Bowo, C. 2015. Respon Pertumbuhan Tanaman Tebu Varietas Bululawang dan Hari Widodo dengan Pemberian Silika. Berkala Ilmiah Pertanian 1(1).

Meidalima, D. dan Kawaty, R.R. 2015. Eksplorasi dan Pengamatan Intensitas Serangan Hama Penting Tanaman Tebu di PTPN VII, Cinta Manis Sumater Selatan. Biosaintifika 7(1):68-76

Pikukuh, P., Djajadi, Tyasmoro, S.Y. dan Aini, N. 2015. Pengaruh Frekuensi dan Konsentrasi Penyemprotan Pupuk Nano Silika (Si) Terhadap Pertumbuhan Tanaman Tebu (Saccharum officinarum L.). Jurnal Produksi Tanaman 3(3): 249- 258

Saeed A. Abro, Rahmatullah Qureshi, Fateh M. Soomro, Ameer Ahmed Mirbahar, and G.S. Jakhar. Effects Of Silicon Levels On Growth And Yield Of Wheat In Silty Loam Soil. Pak. J. Bot., 41(3): 1385-1390

Siswanto, P.D., Kastono, D., dan Yuwono, N.W. 2019. Pengaruh Aplikasi Tiga Jenis Arang dan klon terhadap Pertumbuhan Vegetatif dan Serapan Unsur Silika (Si) Tebu Pt. Perkebunan Nusantara X jengkol Kediri. Vegetalika 8 (3): 192-201

Sudarsono, H., Sunaryo, dan Saefudin. Intensitas Kerusakan pada Beberapa Varietas Tebu Akibat Serangan Penggerek Pucuk Tebu (S. nivella intacta) setelah Aplikasi Zat Pemacu Kemasakan Isoprophylamine Glyphosate. J. Penelitian Pertanian Terapan 11(3): 129-136

Syahri, R., Djajadi, Sumarni, T., dan Nugroho, A. 2016. Pengaruh Pupuk Hijau (Crotalaria juncea L.) dan Konsentrasi Pupuk Nano Silika pada Pertumbuhan dan Hasil Tebu Setelah Umur 9 Bulan. Jurnal Produksi Tanaman 4(1): 73-81

Trisnawati, D.W., Putra, N.S., dan Purwanto, B.H. 2017. Pengaruh Nitrogen dan Silika terhadap Pertumbuhan dan Perkembangan Spodoptera litura pada Kedelai. Planta Tropika 5(1):52-59 